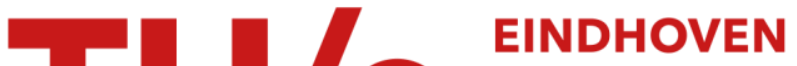

\section{Determination of overall mass transport coefficients in gas diffusion electrodes}

\section{Citation for published version (APA):}

Vermeijlen, J. J. T. T., \& Janssen, L. J. J. (1993). Determination of overall mass transport coefficients in gas diffusion electrodes. Journal of Applied Electrochemistry, 23(1), 26-31. https://doi.org/10.1007/BF00241571

DOI:

10.1007/BF00241571

Document status and date:

Published: 01/01/1993

\section{Document Version:}

Publisher's PDF, also known as Version of Record (includes final page, issue and volume numbers)

\section{Please check the document version of this publication:}

- A submitted manuscript is the version of the article upon submission and before peer-review. There can be important differences between the submitted version and the official published version of record. People interested in the research are advised to contact the author for the final version of the publication, or visit the $\mathrm{DOI}$ to the publisher's website.

- The final author version and the galley proof are versions of the publication after peer review.

- The final published version features the final layout of the paper including the volume, issue and page numbers.

Link to publication

\section{General rights}

Copyright and moral rights for the publications made accessible in the public portal are retained by the authors and/or other copyright owners and it is a condition of accessing publications that users recognise and abide by the legal requirements associated with these rights.

- Users may download and print one copy of any publication from the public portal for the purpose of private study or research.

- You may not further distribute the material or use it for any profit-making activity or commercial gain

- You may freely distribute the URL identifying the publication in the public portal.

If the publication is distributed under the terms of Article 25fa of the Dutch Copyright Act, indicated by the "Taverne" license above, please follow below link for the End User Agreement:

www.tue.nl/taverne

Take down policy

If you believe that this document breaches copyright please contact us at:

openaccess@tue.nl

providing details and we will investigate your claim. 


\title{
Determination of overall mass transport coefficients in gas diffusion electrodes
}

\author{
J. J. T. T. VERMEIJLEN, L. J. J. JANSSEN \\ Faculty of Chemical Engineering, Laboratory of Instrumental Analysis, Eindhoven University of Technology, \\ P.O. Box 513, 5600 MB Eindhoven, The Netherlands
}

Received 2 January 1992; revised 18 May 1992

Gas diffusion electrodes are used for many purposes, for example in fuel cells, in synthesis and as anodes in electrodeposition processes. The behaviour of gas diffusion electrodes has been the subject of many studies. In this work the transport of gas in the gas diffusion electrode, characterized by the overall mass transport coefficient, has been investigated using hydrogen-nitrogen mixtures. A reactor model for the gas compartment of the gas diffusion electrode test cell is proposed to calculate the concentration of hydrogen in the gas compartment as a function of the input concentration of hydrogen and the total volumetric gas flow rate. The mass transport coefficient is found to be independent of variations in hydrogen concentration and volumetric gas flow rate. The temperature dependence of the mass transport coefficient has been determined. A maximum was found at $40^{\circ} \mathrm{C}$.

\begin{tabular}{|c|c|}
\hline Notation & \\
\hline$A_{\mathrm{gd}}$ & geometric electrode surface area $\left(\mathrm{m}^{2}\right)$ \\
\hline$c_{\mathrm{in}}^{\mathrm{gin}}$ & $\begin{array}{l}\text { concentration of reactive component at the } \\
\text { inlet of the gas compartment }\left(\mathrm{mol} \mathrm{m}^{-3}\right)\end{array}$ \\
\hline$c_{\text {out }}$ & concentration of reactive component at the \\
\hline$E$ & potential (V) \\
\hline$E_{\mathrm{e}}$ & equilibrium potential (V) \\
\hline$E_{\mathrm{t}}$ & upper limit potential (V) \\
\hline$F_{\mathrm{v}}$ & volumetric flow rate $\left(\mathrm{m}^{-3} \mathrm{~s}^{-1}\right)$ \\
\hline$F_{\mathrm{v}, \mathrm{H}}$ & volumetric flow rate of hydrogen $\left(\mathrm{m}^{-3} \mathrm{~s}^{-1}\right)$ \\
\hline$F_{\mathrm{v}, \mathrm{N}}$ & volumetric flow rate of nitrogen $\left(\mathrm{m}^{-3} \mathrm{~s}^{-1}\right)$ \\
\hline$F_{\mathrm{v}, \text { in }}$ & $\begin{array}{l}\text { volumetric flow rate at the inlet of the gas } \\
\text { compartment }\left(\mathrm{m}^{-3} \mathrm{~s}^{-1}\right)\end{array}$ \\
\hline$F_{\mathrm{v}, \text { out }}$ & $\begin{array}{l}\text { volumetric flow rate at the outlet of the gas } \\
\text { compartment }\left(\mathrm{m}^{-3} \mathrm{~s}^{-1}\right)\end{array}$ \\
\hline$F_{\mathrm{v}, \text { reaction }}$ & $\begin{array}{l}\text { volumetric flow rate of reactive component } \\
\text { into the gas diffusion electrode }\left(\mathrm{m}^{-3} \mathrm{~s}^{-1}\right)\end{array}$ \\
\hline
\end{tabular}

Faraday constant $\left(\mathrm{A} \mathrm{s} \mathrm{mol}^{-1}\right)$

current for gas diffusion electrode (A)

current density for gas diffusion electrode $\left(\mathrm{A} \mathrm{m}^{-2}\right)$

diffusion limited current for gas diffusion electrode (A)

diffusion limited current density for gas diffusion electrode $\left(\mathrm{A} \mathrm{m}^{-2}\right)$

calculated diffusion limited current for gas diffusion electrode (A)

calculated diffusion limited current density for gas diffusion electrode $\left(\mathrm{A} \mathrm{m}^{-2}\right)$

current for hydrogen production (A)

mass transport coefficient calculated from $c_{\text {out }}\left(\mathrm{m} \mathrm{s}^{-1}\right)$

number of electrons involved in electrode reaction

temperature $\left({ }^{\circ} \mathrm{C}\right)$

molar volume of gas $\left(\mathrm{m}^{3} \mathrm{~mol}^{-1}\right)$

overpotential (V)

\section{Introduction}

Gas diffusion electrodes have been developed for use in fuel cells for the direct conversion of chemical into electrical energy. Recently, alternative applications for gas diffusion electrodes have been proposed, e.g. in electrodeposition processes [1-3]. Due to the high current densities required in these applications, the mass transport in the electrodes is of great importance.

Gas diffusion electrodes have been the object of many studies concerning, for example, the electrocatalytic behaviour, electrokinetics, diffusion, morphology, optimisation of performance, etc. [4-7]. Many models for kinetics and mass transport have been suggested to account for the behaviour of gas diffusion electrodes $[8,9]$. These studies contribute to

the understanding of the working mechanism of gas diffusion electrodes.

In this work, gas diffusion electrodes will be characterized by the overall mass transport coefficient under diffusion-limited conditions. Mass transport coefficients have been determined using hydrogennitrogen mixtures.

The method presented was used to characterize the flow conditions in the gas chamber of the experimental cell. This method can be used to compare the magnitude of diffusion resistance in gas diffusion electrodes.

\section{Experimental details}

The experimental setup is shown in Fig. 1. The experimental cell was a Perspex cell divided into two compartments, viz. the gas compartment and the solution 


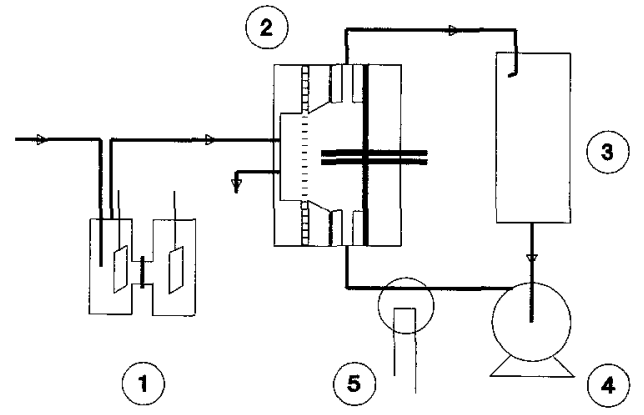

Fig. 1. Schematic illustration of the experimental setup. (1) hydrogen generation cell, (2) gas diffusion electrode test cell, (3) solution storage vessel, (4) pump and (5) heat exchanger.

compartment, by a gas diffusion electrode, and schematically presented in Fig. 2.

The gas diffusion electrodes used were 'fuel cell grade electrodes' on Toray paper, purchased from E-TEK, USA. These electrodes consist of carbon black bonded with Teflon on a Toray paper carrier. The active layer with a thickness of approximately $0.1 \mathrm{~mm}$ consists of platinum dispersed on Vulcan $\mathrm{XC}-72$. The total electrode thickness measured approximately $0.55 \mathrm{~mm}$.

The gas compartment measured $20 \times 20 \times 8 \mathrm{~mm}^{3}$. The gas was supplied through a tube with an inner diameter of $5 \mathrm{~mm}$ at the top of the gas compartment. The gas outlet was situated at the bottom of the gas compartment to prevent the liquid condensation products filling the gas compartment.

An expanded titanium mesh was used as the current collector for the gas diffusion electrode. An area of $20 \times 20 \mathrm{~mm}^{2}$ of the electrode was exposed to the gas and the solution. Measurements showed that the screening of the gas side by the titanium mesh had no effect on the data obtained. The space between the gas compartment and the liquid compartment at the edge of the gas diffusion electrode was sealed to prevent transport of air oxygen to the electrode.

The solution compartment with a total volume of $10.8 \mathrm{~cm}^{-3}$ was equipped with a platinum counter electrode measuring $26 \times 26 \mathrm{~mm}^{2}$. The distance between working electrode and counter electrode was $18 \mathrm{~mm}$. The reference electrode capillary was situated in a hole in the middle of the counter electrode and pointed towards the gas diffusion (working) electrode. A

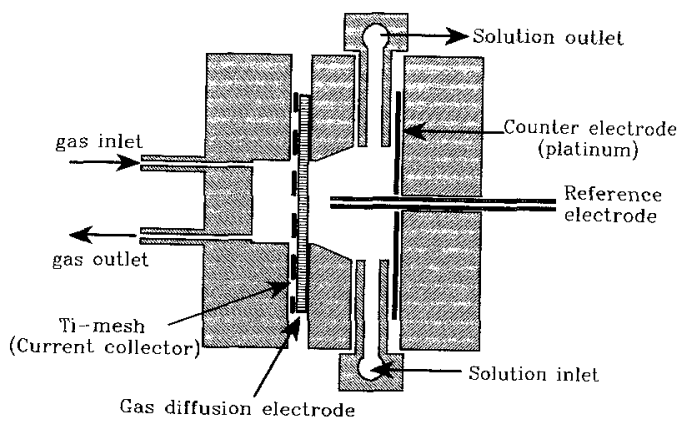

Fig. 2. Schematic illustration of the gas diffusion electrode test cell. thread was inserted in the capillary to prevent gas bubbles from entering. The distance between working electrode and the tip of the Luggin capillary was adjustable. A tube connected to this Luggin capillary contained the reference electrode, being a saturated calomel electrode.

The solution used was $0.5 \mathrm{M} \mathrm{H}_{2} \mathrm{SO}_{4}$. The $\mathrm{pH}$ of the solution remained practically constant during the experiments and needed no adjustment. The return flow from the cell into the solution storage vessel was led over the vessel wall to remove the hydrogen gas bubbles produced at the counter electrode from the solution. Pre-electrolysis showed that stripping the dissolved hydrogen from the solution solution with nitrogen was of no influence on the current observed. Therefore, nitrogen stripping was not applied in the measurements presented in this study. The solution was recirculated through the solution compartment at a rate of $300 \mathrm{~cm}^{3} \mathrm{~min}^{-1}$. Increasing or decreasing this rate did not affect the currents measured. This particular rate was chosen to prevent accumulation of the hydrogen gas formed at the counter electrode. The solution entered the cell at the bottom of the solution compartment and left at the top to ensure entrainment of the gas evolved at the counter electrode. The temperature was kept constant by means of a heat exchanger just before the inlet of the solution compartment.

Hydrogen added to a nitrogen stream was used for mass transport measurements. The nitrogen flow was controlled by means of a valve and a flow meter. The flowmeters used were Fischer \& Porter 08F-1/16-08 for low volumetric rates and $02 \mathrm{~F}-1 / 8-12-5$ for volumetric rates up to $850 \mathrm{~cm}^{3} \mathrm{~min}^{-1}$, both with sapphire floats. The hydrogen was generated at constant current in an electrochemical $\mathrm{H}$-cell filled with $4 \mathrm{M} \mathrm{KOH}$. The cell was fitted with two platinum electrodes. The anodic and cathodic halves of the cell were divided by a Nafion ${ }^{\mathbb{R}}$ ion-exchange membrane to separate oxygen and hydrogen gas. The amount of hydrogen added to the nitrogen stream at stationary conditions is exactly known and calculated from the current applied.

Cyclic voltammograms were recorded by scanning the potential over a $1 \mathrm{~V}$ range between the equilibrium potential of the electrode, $E_{\mathrm{e}}$, and $E_{\mathrm{t}}$, the more positive potential. The potentials were applied through a Solartron 1286 Electro Chemical Interface (ECI) controlled by a microcomputer. The potential range was scanned at a rate of $5 \mathrm{mV} \mathrm{s}^{-1}$ in the ECI 1286's stepped sweep mode at a stepping rate of $1 \mathrm{~s}^{-1}$.

Ohmic drops between the working electrode and the reference electrode were measured by means of electrochemical impedance measurements. The impedance spectra were measured with the ECI 1286 and the Solartron 1250 Frequency Response Analyser (FRA) controlled by a microcomputer and the EISData software package. The ohmic drop was computed from the impedance data using the EISCalc software package. Both EISData and EISCalc were obtained from J. Schram, TU Delft, The Netherlands. 


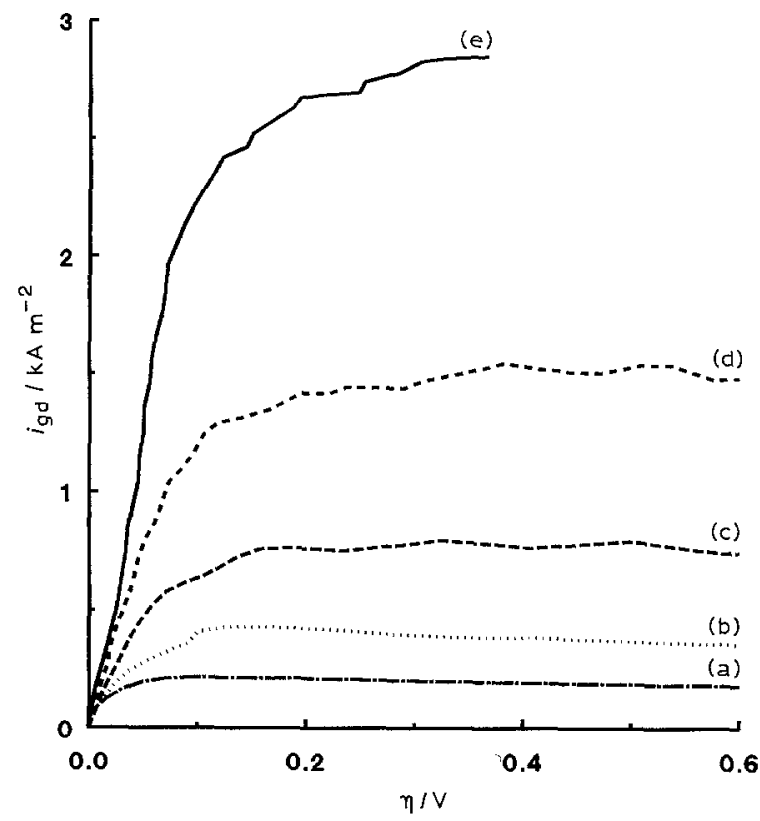

Fig. 3. The gas diffusion electrode current density, $i_{\mathrm{gd}}$, as a function of the overpotential, $\eta$, at a temperature of $30^{\circ} \mathrm{C}$. Volumetric nitrogen flow rate $F_{\mathrm{v}, \mathrm{N}}=2.33 \mathrm{~cm}^{3} \mathrm{~s}^{-1}$. The hydrogen inlet concentration, $c_{\text {in }} / \mathrm{mol} \mathrm{m}^{-3}:=$ (a) 0.28 , (b) 0.55 , (c) 1.08 , (d) 2.12 and (e) 4.04 .

\section{Results}

The hydrogen content of the inlet gas stream was varied by applying currents in the range from 0.005 to $2 \mathrm{~A}$ to the hydrogen generation cell. Moreover, the volumetric rate of nitrogen was varied in the range from 0.1 to $15 \mathrm{~cm}^{3} \mathrm{~s}^{-1}$.

Figure 3 shows a typical set of current density-overpotential curves for a gas diffusion electrode with $0.50 \mathrm{mg} \mathrm{cm}^{-2} \mathrm{Pt}$ loading. The results were obtained for various hydrogen concentrations $c_{\text {in }}$ in the gas feed flow. The overpotential $\eta$ was corrected for the ohmic drop. The current density-overpotential curves clearly show the kinetically controlled overpotential region preceeding the diffusion limited plateaus. Increasing the overpotential to values above approximately $0.6 \mathrm{~V}$ leads to a decrease in current density. This decrease is caused by oxidation of the platinum catalyst particles. The diffusion limited current density is calculated as the mean current density in the overpotential interval from 0.3 to $0.5 \mathrm{~V}$. The direction of the potential sweep had practically no effect on the limited current density for high hydrogen concentrations. For low hydrogen concentrations, the mean value of the mean current densities from increasing and decreasing overpotential has been calculated to account for double-layer charging effects.

Figure 4 shows the relation between the hydrogen production current applied in the $\mathrm{H}$-cell, $I_{\mathrm{hp}}$, and the diffusion limited current in the gas diffusion electrode test cell, $I_{\mathrm{gd}, 1}$ for various volumetric nitrogen flow rates, $F_{\mathrm{v}, \mathrm{N}}$, applied. From this plot it follows that very high conversions $\left(I_{\mathrm{gd}, 1} / I_{\mathrm{hp}}\right)$ can be obtained, for instance $59 \%$ at $F_{\mathrm{v}, \mathrm{N}}=2.33 \mathrm{~cm}^{3} \mathrm{~s}^{-1}$ and $I_{\mathrm{hp}}=1 \mathrm{~A}$. The conversion is dependent upon the space time of the feed gas in the gas compartment, as can be seen from the curves for different nitrogen flow rates.

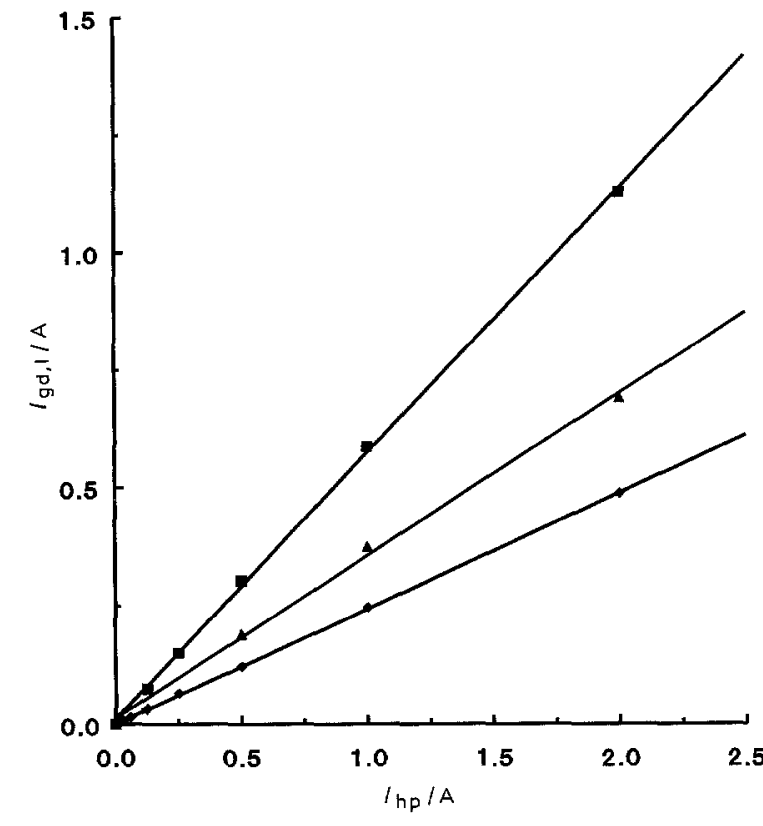

Fig. 4. The diffusion limited current, $I_{\mathrm{gd}, 1}$, as a function of the hydrogen production current, $I_{\mathrm{hp}}$, at a temperature of $30^{\circ} \mathrm{C}$. The volumetric nitrogen flow rate, $F_{\mathrm{v}, \mathrm{N}} / \mathrm{cm}^{3} \mathrm{~s}^{-1}:$ (口) 2.33 , (4) 5.08 and (४) 8.25 .

Figure 5 shows a curve on a double logarithmic scale representing the diffusion limited current density, $i_{\mathrm{gd}, 1}$, as a function of the hydrogen concentration in the feed gas at the inlet of the gas compartment of the gas diffusion cell, $c_{\text {in }}$, at a constant nitrogen flow rate and at a constant temperature. The $c_{\mathrm{in}}$ is varied by variation of $I_{\mathrm{hp}}$. From this plot it follows that there is an almost linear relationship between $c_{\text {in }}$ and $i_{\mathrm{gd}, 1}$ at a constant $F_{\mathrm{v}, \mathrm{N}}$.

Figure 6 shows, on a double logarithmic scale, the diffusion limited current density, $i_{\mathrm{gd}, 1}$, as a function of the hydrogen concentration in the gas at the inlet of

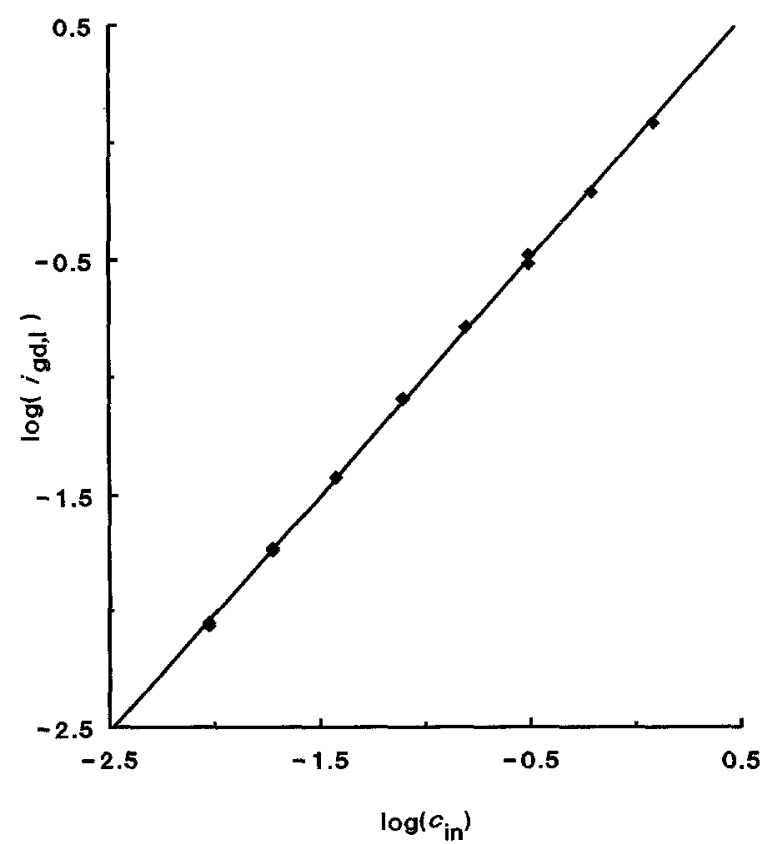

Fig. 5. The diffusion limited current density, $i_{\mathrm{gd}, 1}$, as a function of the hydrogen inlet concentration, $c_{\text {in }}$, on a double logarithmic scale at a temperature of $30^{\circ} \mathrm{C}$ and at a constant volumetric nitrogen flow rate of $2.33 \mathrm{~cm}^{3} \mathrm{~s}^{-1}$. 


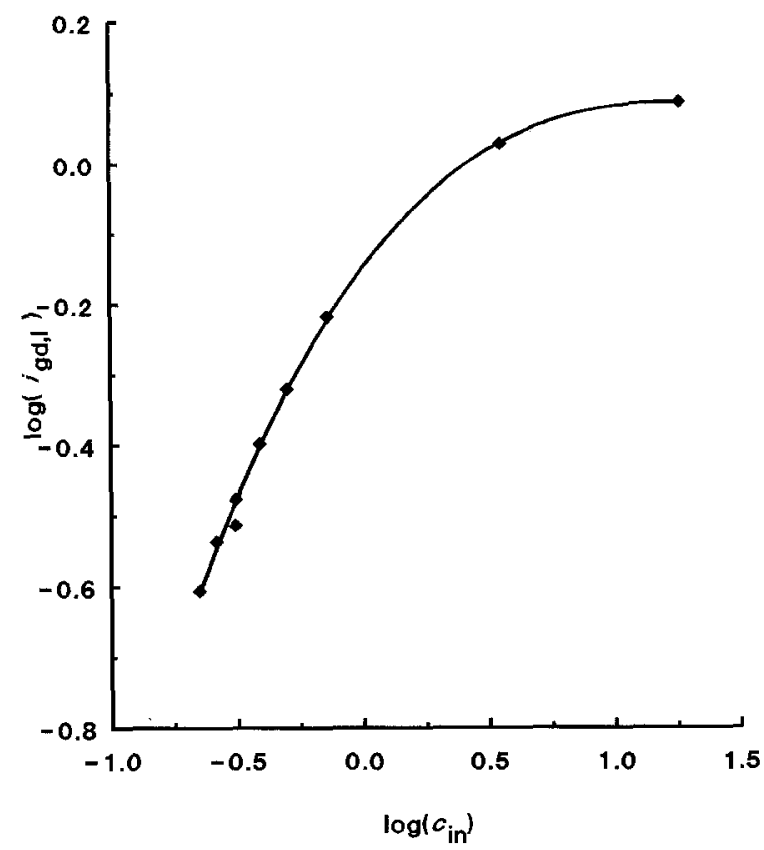

Fig. 6. The diffusion limited current density, $i_{\text {ad, } 1}$, as a function of the hydrogen inlet concentration, $c_{\text {in }}$, on a double logarithmic scale at a temperature of $30^{\circ} \mathrm{C}$ and at a constant hydrogen production current $I_{\mathrm{hp}}=0.5 \mathrm{~A}$.

the gas diffusion cell, $c_{\mathrm{in}}$, for constant $I_{\mathrm{hp}}$ and various $F_{\mathrm{v}, \mathrm{N}}$. The almost linear relationship as observed in Fig. 5 is absent. The molar flow rate of hydrogen through the gas compartment does not solely determine the diffusion limited current density.

Figure 7 shows typical plots of the influence of temperature, $T$, on the diffusion limited current density $i_{\mathrm{gd}, 1}$ at constant $F_{\mathrm{v}, \mathrm{N}}$ and various hydrogen concentrations $c_{\mathrm{in}}$. The maximum in the $i_{\mathrm{gd}, \mathrm{I}}-T$ curves is situated around $40^{\circ} \mathrm{C}$ for every hydrogen concentration.

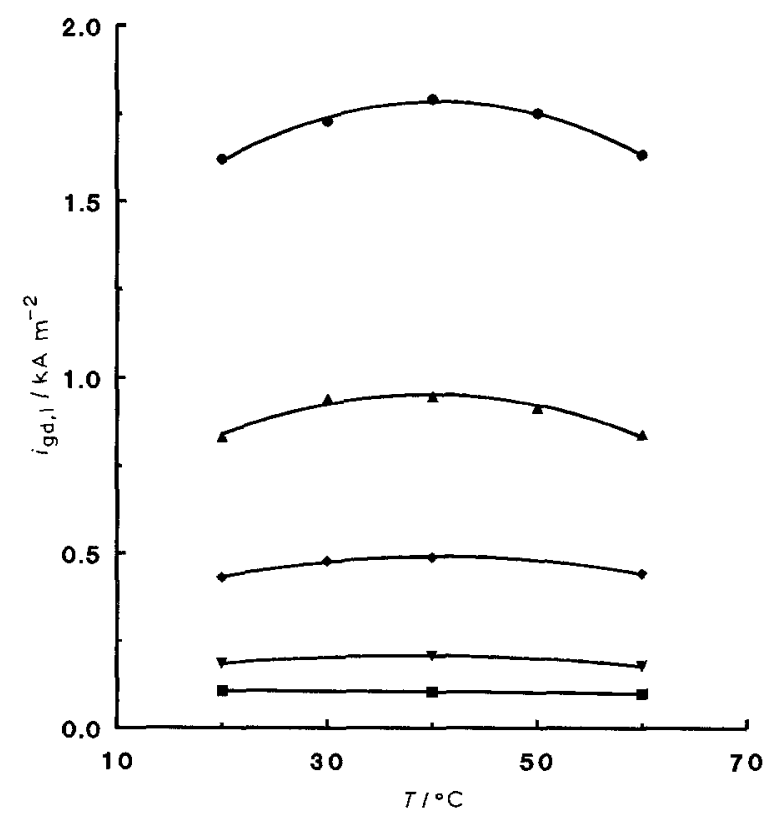

Fig. 7. The diffusion limited current density, $i_{\mathrm{gd}, 1}$, as a function of the temperature, $T$, at a constant volumetric nitrogen flow rate $F_{\mathrm{y}, \mathrm{N}}=5.08 \mathrm{~cm}^{3} \mathrm{~s}^{-1}$ and at hydrogen inlet concentration, $c_{\mathrm{in}} / \mathrm{mol} \mathrm{m}^{-3}$ :

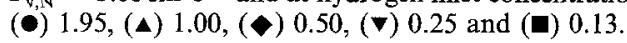

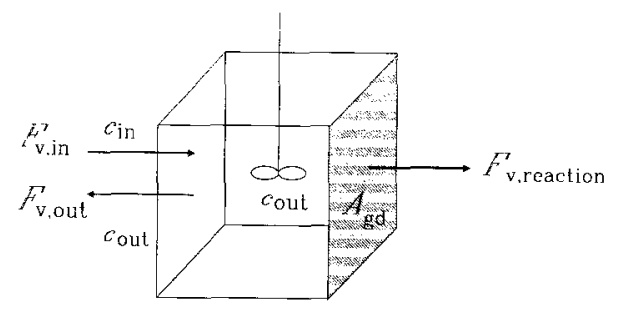

Fig. 8. Schematic illustration of an ideal constant flow stirred tank reactor (CSTR).

\section{Theory for a CSTR model}

An ideal constant flow stirred tank reactor (CSTR) is an ideal steady-state flow reactor in which the contents are perfectly mixed and uniform throughout [10]. Thus the exit stream from this reactor has the same composition as the contents of the reactor. A schematic representation of a CSTR is given in Fig. 8.

It is assumed that the gas compartment of the gas diffusion electrode test cell behaves as an ideal constant flow stirred tank reactor. This gas compartment is fed by a mixture of nitrogen and hydrogen. Hydrogen gas is oxidized in the gas diffusion electrode. Consequently, the hydrogen concentration in the gas in and leaving the gas compartment is lower than the concentration in the gas entering the gas compartment. Due to this conversion of hydrogen gas, the volumetric gas flow rate will be affected.

The total volumetric gas flow balance can be formulated as

$$
F_{\mathrm{v}, \text { in }}=F_{\mathrm{v}, \text { out }}+F_{\mathrm{v}, \text { reaction }}
$$

It is assumed that both nitrogen and hydrogen behave as ideal gases. Also, the pressure of the gas is assumed equal throughout the whole gas compartment and constant under all circumstances. Moreover, it is assumed that the mass transfer coefficient $k_{\mathrm{s}}$ is constant for the whole geometric surface area of the electrode.

The total molar flow balance for a CSTR reactor with an electrochemical surface reaction under control of linear diffusion is formulated as [11]:

$$
F_{\mathrm{v}, \text { in }} c_{\text {in }}=F_{\mathrm{v}, \text { out }} c_{\text {out }}+k_{\mathrm{s}} A_{\mathrm{gd}} c_{\text {out }}
$$

Under the assumptions made previously the volumetric gas flow rate used for the reaction can be written as:

$$
F_{\mathrm{v}, \text { reaction }}=k_{\mathrm{s}} A_{\mathrm{gd}} c_{\mathrm{out}} V_{\mathrm{m}}
$$

This equation describes the decrease in the volumetric flow due to hydrogen oxidation at the gas diffusion electrode.

Combination of Equations 1, 2 and 3 and rearrangement gives:

$$
k_{\mathrm{s}} A_{\mathrm{gd}} V_{\mathrm{m}} c_{\mathrm{out}}^{2}-\left(F_{\mathrm{v}, \text { in }}+k_{\mathrm{s}} A_{\mathrm{gd}}\right) c_{\mathrm{out}}+F_{\mathrm{v}, \text { in }} c_{\text {in }}=0
$$

From Equation 4 the output concentration $c_{\text {out }}$ for certain $k_{\mathrm{s}}$ and $A_{\mathrm{gd}}$ as a function of $F_{\mathrm{v} \text {, in }}$ and $c_{\mathrm{in}}$ can be solved. Since the hydrogen concentration within the gas compartment is $c_{\text {out }}$, the diffusion limited current 
Table 1. Mass transport coefficients, $k_{s}$, at various temperatures, $T$, as calculated from experiments with a volumetric nitrogen flow rate of $5.08 \mathrm{~cm}^{3} \mathrm{~s}^{-1}$ and a hydrogen inlet concentration of $1.95 \mathrm{molm} \mathrm{m}^{-3}$

\begin{tabular}{ll}
\hline Temperature $/{ }^{\circ} \mathrm{C}$ & $k_{\mathrm{s}} \times 10^{3} / \mathrm{m} \mathrm{s}^{-1}$ \\
\hline 20 & 6.28 \\
30 & 6.92 \\
40 & 7.31 \\
50 & 7.06 \\
60 & 6.35 \\
\hline
\end{tabular}

can be written as:

$$
I_{\mathrm{gd}, 1}=n \mathscr{F} k_{\mathrm{s}} A_{\mathrm{gd}} c_{\text {out }}
$$

Combining Equations 4 and 5 and rearranging gives an equation for the diffusion limited current as a function of $F_{\mathrm{v}, \text { in }}$ and $c_{\mathrm{in}}$ at certain $A_{\mathrm{gd}}$ and $k_{\mathrm{s}}$ values:

$$
\begin{aligned}
I_{\mathrm{gd}, 1, \mathrm{calc}}= & \frac{n \mathscr{F}}{2 V_{\mathrm{m}}}\left[\left(F_{\mathrm{v}, \text { in }}+k_{\mathrm{s}} A_{\mathrm{gd}}\right)\right. \\
& \left.-\sqrt{\left(F_{\mathrm{v}, \text { in }}+k_{\mathrm{s}} A_{\mathrm{gd}}\right)^{2}-4 k_{\mathrm{s}} A_{\mathrm{gd}} F_{\mathrm{v}, \text { in }} V_{\mathrm{m}} c_{\mathrm{in}}}\right]
\end{aligned}
$$

Equation 6 can also be used to determine the value of $k_{\mathrm{s}}$ at a measured value of $I_{\mathrm{gd}, 1}$. Both $i_{\mathrm{gd}, 1}$ and $i_{\mathrm{gd}, 1, \mathrm{calc}}$ are calculated by division of $I_{\mathrm{gd}, 1}$ and $I_{\mathrm{gd}, 1, \text { calc }}$ by $A_{\mathrm{gd}}$.

\section{Discussion}

Both the input and the output of the gas compartment are situated perpendicularly to the electrode surface. This enables a good mixing of the gas present in the gas compartment of the gas diffusion electrode test cell. Moreover, the diffusion of hydrogen in the gas is a fast process. Thus, concentration gradients will be levelled rapidly. These considerations support the choice of a CSTR model as a reliable model for the behaviour of the gas compartment of the test cell.

The mass transport coefficients $k_{\mathrm{s}}$ have been calculated using Equation 6 . The calculated values of $k_{\mathrm{s}}$ are tabulated in Table 1 for the measurements with a nitrogen flow rate of $5.08 \mathrm{~cm}^{3} \mathrm{~s}^{-1}$ and an initial hydrogen concentration of $1.95 \mathrm{molm}^{-3}$. The $i_{\mathrm{gd}, 1}-T$ curve for these measurements is represented by the top curve of Fig. 7.

For the experiments shown in Fig. 5, in which the hydrogen concentration $c_{\text {in }}$ is varied by variation of the hydrogen production current at constant nitrogen flow rate, it has been calculated that the mean $k_{\mathrm{s}}=6.90 \times 10^{-3} \mathrm{~m} \mathrm{~s}^{-1}$. This value agrees well with $k_{\mathrm{s}}$ from Table 1 , being $6.92 \times 10^{-3} \mathrm{~m} \mathrm{~s}^{-1}$.

For the experiments from Fig. 6, in which the hydrogen concentration $c_{\text {in }}$ is varied by variation of the nitrogen flow rate at constant hydrogen production current, the $k_{\mathrm{s}}$ value for the experiment with the nitrogen flow rate $F_{\mathrm{v}, \mathrm{N}}=0.08 \mathrm{~cm}^{3} \mathrm{~s}^{-1}$ has been left out because of the inaccuracy in the low flow rate $F_{\mathrm{v} \text {,in }}$ and the extremely high conversion, viz. $98 \%$. It is found that for the other experiments the mean $k_{\mathrm{s}}=$ $7.5 \times 10^{-3} \mathrm{~m} \mathrm{~s}^{-1}$, which agrees with the calculated value from Table 1 .

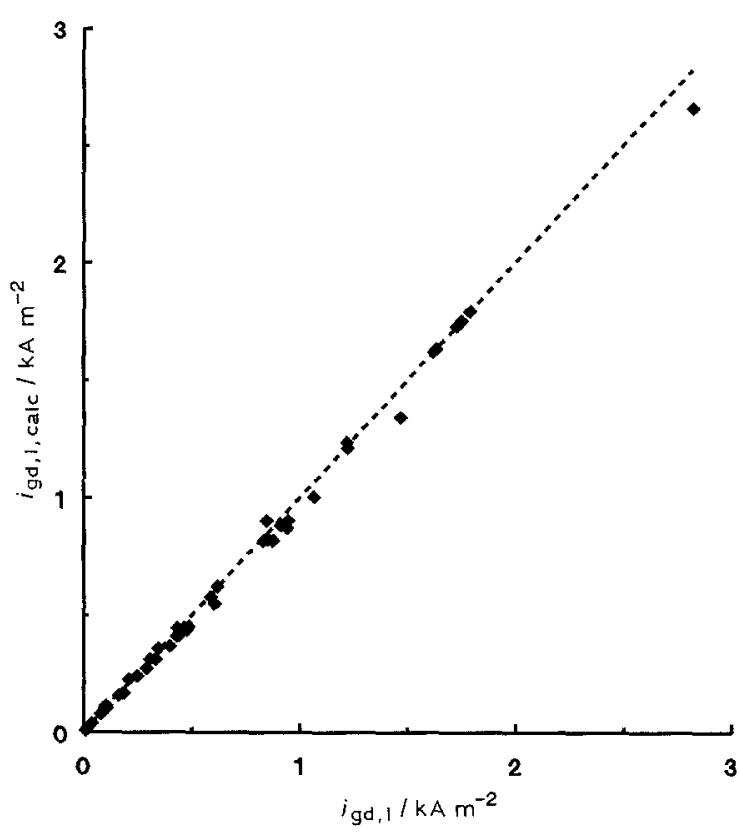

Fig. 9. The measured diffusion limited current density, $i_{\mathrm{gd}, 1}$, against the calculated diffusion limited current density, $i_{\mathrm{gd}, \mathrm{l} \text {, calc }}$, at various hydrogen inlet concentrations, volumetric nitrogen flows and temperatures. The dashed line represents $i_{\mathrm{gd}, 1}=i_{\mathrm{gd}, \mathrm{l}, \mathrm{cal}}$.

Using $k_{\mathrm{s}}$ from Table $1, i_{\mathrm{gd}, 1, \text { calc }}$ at different volumetric flow rates $F_{\mathrm{v} \text {,in }}$ and initial hydrogen concentrations $c_{\text {in }}$ was calculated for a number of measurements. Figure 9 shows the calculated data versus the measured data, $i_{\text {gd, },}$. There is a good agreement between the calculated and the measured diffusion limited current density as is shown in Fig. 9 for a large number of experiments with various ratio's between $F_{\mathrm{v}, \mathrm{H}}$ and $F_{\mathrm{v}, \mathrm{N}}$.

It is concluded that the calculated mass transport coefficient $k_{\mathrm{s}}$ is independent of the input hydrogen concentration $c_{\text {in }}$ and gas flow rate $F_{\mathrm{v}, \text { in }}$. Moreover, from the increase in $i_{\mathrm{gd}, \mathrm{I}}$ with increasing temperature in the temperature range where the water vapour pressure is very low, it is concluded that the rate for the oxidation of hydrogen is determined by the transport of hydrogen inside the gas diffusion electrode. Bagotskii et al. have investigated the behaviour of oxygen gas diffusion electrodes with regard to the effect of nitrogen as gaseous diluent [14-18]. The theoretical dependence of the limiting current for oxygen on the oxygen partial pressure is presented. The experimental relation between current and oxygen partial pressure was found to show an inflection at large electrode polarisations due to a limited supply of oxygen. Moreover, the deviations of calculated from experimental limiting currents could be attributed to the presence of water vapour. Luzhin et al. have also studied the effect of an inert gas component of a binary gas mixture on the mass transfer of oxygen in the gas phase of a porous electrode $[19,20]$. Computer calculations showed that the concentration of the inert component increased sharply across the electrode thickness.

The current for hydrogen oxidation is diffusion limited at overpotentials larger than approximately 
$0.2 \mathrm{~V}$. The maximum overpotential to obtain the diffusion limited current is approximately $0.6 \mathrm{~V}$ due to the formation of an oxide layer on platinum particles.

The temperature dependence from Fig. 7 can be easily explained. On increasing the temperature, the diffusivity of hydrogen in the gas diffusion electrode increases. On the other hand, the hydrogen gas pressure in the hydrophobic part of the gas diffusion electrode decreases because of the increase in water vapour pressure. From partial water pressure data [12] it follows that the vapour pressure increases steeply at temperatures over approximately $40^{\circ} \mathrm{C}$. Thus, the diffusion limited current increases with increasing temperature in the temperature range where the increase in diffusivity is the dominant factor and decreases in the range where the decrease in hydrogen concentration is the most important factor.

In [13] a maximum is found near $60^{\circ} \mathrm{C}$ for rotating disc experiments in dilute $\mathrm{H}_{2} \mathrm{SO}_{4}$. The shift of the maximum to a lower temperature is caused by the transport of water vapour in a direction opposed to that of the hydrogen flow in the gas layer of the gas diffusion electrode.

\section{Acknowledgement}

This work was supported by Hoogovens IJmuiden, the Netherlands.

\section{References}

[1] N. Furuya and S. Motoo, J. Electroanal. Chem. 179 (1984) 297.

[2] L. J. J. Janssen and G. C. van Haastrecht, Eur. Pat. Appl. EP 346981 (1989).

[3] K. Wiesener, A. Möbius, Extended abstracts, 39th Annual Meeting, International Society of Electrochemisty (1988) 64.

[4] S. Motoo, M. Watanabe, N. Furuya, J. Electroanal. Chem. 160 (1984) 351.

[5] K. A. Striebel, F. R. McLarnon, E. J. Cairns, J. Electrochem. Soc. 137 (1990) 3360.

[6] F. G. Will, ibid. 110 (1963) 145.

[7] V. Alderucci, V. Recupero, L. Pino, R. Di Leonardo, D. L. Cocke, N. Giordano, F. Parmigiani, J. Appl. Electrochem 20 (1990) 811.

[8] K. Y. Chan, G. S. Efthymiou, J. F. Cocchetto, Electrochim, Acta 32 (1987) 1227.

[9] D. M. Bernardi, M. W. Verbrugge, AlChE J. 37 (1991) 1151.

[10] O. Levenspiel, 'Chemical Reaction Engineering', John Wiley \& Sons, New York (1972).

[11] D. J. Pickett, 'Electrochemical Reactor Design', Elsevier Scientific Publishing Company, Amsterdam (1977).

[12] R. C. Weast (ed.), 'Handbook of Chemistry and Physics', CRC Press, 61st edn., Boca Raton, Florida (1981).

[13] M. Breiter, K. Hoffmann, Z. Electrochem. 64 (1960) 462.

[14] Yu. G. Chirkov, G. V. Shteinberg, A. P. Baranov, V. S. Bagotskii, Elektrokhimiya 9 (1973) 655.

[15] Idem, ibid. 9 (1973) 659.

[16] Idem, ibid. 10 (1974) 322

[17] Idem, ibid. 10 (1974) 326.

[18] rdem, ibid. 12 (1976) 1025

[19] V. K. Luzhin, A. G. Kicheev, N. V. Korovin, ibid. 11 (1975) 943.

[20] Idem, ibid. 11 (1975) 946. 